Nursing News: Jurnal Ilmiah Keperawatan Vol 5, No 2 Tahun 2021 ,hal $45 .--55$

Tersedia online di https://publikasi.unitri.ac.id/index.php/fikes

ISSN 2527-9823(online)

\title{
Perilaku Penderita Hipertensi di Rumah Sakit X
}

\author{
Yasinta Indah Sulistyaningrum ${ }^{1)}$, I Wayan Artana ${ }^{2)}$, Alfiery Leda Kio ${ }^{3)}$ \\ Program Studi S1 Keperawatan Sekolah Tinggi Ilmu Kesehatan Bina Usadha Bali \\ Email: yasintaareta@gmail.com
}

\begin{abstract}
The prevalence of hypertension is still high, despite various treatments have been done. The success of bypertension treatment depends on the behavior of people with hypertension during treatment. This study aimed to understand the behavior of hypertensive sufferers at X Hospital which supported or unsupported the health. The qualitative study with phenomenology method was involved six informants. Data collection was done by in-depth interviews, observation, and analysis based on Miles \& Huberman principals. This research found the behaviors that support the bealth of hypertension sufferer's are the application of a low salt diet, cessation of cigarette and alcohol consumption, increase in activity and exercise, regulation of sleep and rest needs, application of stress control methods, and hypertension treatment and care. Overall, the informants have implementesd that six behaviors, but in the aspects of treatment and care of hypertension it has not been implemented properly. It is hoped that the nurses in the hospital need to provide education about healthy lifestyle independently that able to lower hypertension and emphasize on the importance of undergoing regular treatment and care to bealth services.
\end{abstract}

Keywords: behavior, bypertensive patients, bypertension, education, regular treatment

\begin{abstract}
ABSTRAK
Prevalensi hipertensi ditemukan masih tinggi walaupun berbagai upaya penanganan telah dilakukan. Keberhasilan perawatan hipertensi bergantung pada perilaku penderita hipertensi selama menjalani pengobatan. Penelitian ini bertujuan untuk memahami perilaku penderita hipertensi di Rumah Sakit X yang bersifat mendukung maupun tidak mendukung kesehatan. Studi kualitatif dengan metode fenomenologi dilaksanakan telah melibatkan sejumlah enam orang informan. Pengumpulan data dilakukan dengan wawancara mendalam, observasi, dan dianalisis berdasarkan prinsip analisis Miles \& Huberman. Penelitian ini menemukan perilaku yang mendukung kesehatan penderita hipertensi yaitu penerapan diet rendah garam, penghentian konsumsi rokok dan alkohol, peningkatan aktivitas dan olahraga, pengaturan kebutuhan tidur dan istirahat, penerapan metode kontrol stres, serta pengobatan dan perawatan hipertensi. Secara keseluruhan, semua informan telah menerapkan ke enam perilaku tersebut, namun pada aspek pengobatan dan perawatan hipertensi belum sepenuhnya dilaksanakan dengan tepat. Perawat di rumah sakit diharapkan perlu memberikan edukasi mengenai pola hidup sehat secara mandiri yang bisa menurunkan hipertensi dan menekankan pentingnya menjalani pengobatan dan perawatan secara rutin ke pelayanan kesehatan
\end{abstract}

Kata Kunci: edukasi; hipertensi; kontrol rutin; perilaku; pasien hipertensi

Cara mengutip: Sulistyaningrum,Y.I., Artana, I.W., Kio, AL.(2021). Perilaku Penderita Hipertensi di Rumah Sakit X. Nursing News: Jurnal Ilmiah Keperawatan. Vol 5, No 2, 2021, hal 45-55. Retrieved from https://publikasi.unitri.ac.id/index.php/fikes/article/view/2300 


\section{PENDAHULUAN}

Hipertensi dikenal sebagai salah satu penyebab penting pemicu kematian prematur di seluruh dunia (Bell et al., 2015). Hasil konsensus oleh the American Heart Association di Asia menyebutkan bahwa penyebab tingginya hipertensi di Asia menekankan pada konsumsi diet tinggi garam, pemantauan tekanan darah disertai konsumsi obat antihipertensi yang tidak adekuat. (Kario et al., 2018). Tekanan darah tinggi akan meningkatkan peluang penderita terserang penyakit kardiovaskular sebesar 4,5 kali lebih besar dibandingkan pada tekanan darah normal (Murakami, et al., 2015 dalam Soenarta et al., 2020).

World Health Organization mengestimasi sejumlah 1,13 miliar orang di seluruh dunia telah mengalami hipertensi (World Health Organization, 2019b). Prevalensi hipertensi di Indonesia mengalami peningkatan dari 25,7\% (2013) menjadi 34,1\% (2018) berdasarkan data Riset Kesehatan Dasar dengan usia 75 tahun ke atas menduduki persentase tertinggi $(69,5 \%)$. Berdasarkan jumlah tersebut, ditemukan $13,3 \%$ tidak minum obat dan $32 \%$ tidak mengkonsumsi obat secara rutin. Alasan yang ditemukan pada keengganan untuk minum obat dari pasien hipertensi antara lain merasa sudah sehat, tidak melakukan kunjungan rutin ke fasilitas kesehatan, memilih minum obat tradisional, sering lupa mengkonsumsi obat, tidak mampu membeli obat, tidak tahan efek obat dan ketersediaan obat yang tidak memadai (Kemenkes RI, 2018). Dinas Kesehatan Kota Denpasar 2018 melaporkan estimasi penderita hipertensi mencapai 127.638, namun hanya 7,6\% yang telah menjalani perawatan sesuai standar (Dinas Kesehatan Kota Denpasar, 2018).

Keengganan dalam mengkonsumsi obatobatan antihipertensi sangat dipengaruhi oleh keyakinan terkait ancaman kesehatan pribadi dan tingkat efektivitas obat. Apabila perilaku ini diikuti pula dengan keterbatasan ketersediaan obat, keengganan untuk menjalani pengobatan alternatif dan rendahnya rekomendasi pengobatan yang sesuai, maka akan sangat berisiko terjadinya komplikasi (Rahmawati \& Bajorek, 2018). Perilaku yang dimaksud adalah terkait dengan keyakinan penderita dalam merawat dirinya, kemampuan dalam mengukur tekanan darah serta mengenali perubahan kondisi kesehatan dan manajemen gejala yang menekankan pada pengobatan, pembatasan merokok, diet restriksi garam, kontrol berat badan, 
aktivitas fisik dan manajemen stres (Park \& Kim, 2016).

Data Rumah Sakit X menunjukkan kunjungan pasien hipertensi meningkat dari tahun ke tahun. Jumlah pasien tahun 2017 mencapai 425, 2018 menjadi 486 dan 2019 berjumlah 507 orang. Selanjutnya, data bulan Januari hingga Maret 2020 telah tercatat 95 pasien yang ditangani. Studi pendahuluan pada bulan April melalui wawancara telah dilakukan pada sepuluh pasien hipertensi. Ditemukan hanya enam orang pasien yang menyatakan minum obat tensi secara teratur dengan alasan takut terkena komplikasi stroke. Empat pasien lainnya tidak rutin minum obat, namun hanya menerapkan mengurangi konsumsi garam dan daging merah.

Perhatian yang rendah terhadap kesehatan dilaporkan sebagai kontributor utama dari rendahnya kepatuhan pengobatan dan kontrol penyakit (Cano-Gutierrez et al., 2015). Park \& Kim, (2016) mengemukakan bahwa fokus perawatan pada hipertensi yaitu perilaku yang dapat meningkatkan kepatuhan terhadap pengobatan, pembatasan merokok, diet restriksi garam, kontrol berat badan, aktivitas fisik dan manajemen stress. Namun, pada praktiknya masih terdapat beberapa perilaku yang tidak mendukung kesehatan sehingga menjadi pemicu hipertensi yang tidak terkontrol. Perilaku tersebut antara lain konsumsi alkohol yang berat, ketidakpatuhan pada diet yang direkomendasikan, dan kegemukan (Cherfan et al., 2020). Secara khusus pada pasien dewasa, faktor risiko independen yang ditemukan yaitu ketidakpatuhan pada pengobatan antihipertensi, ketidakpatuhan pada aktivitas fisik, ketidakpatuhan pada penghentian alkohol sehingga terjadi peningkatan kasus hipertensi tidak terkontrol (Gebremichael et al., 2019). Berdasarkan uraian tersebut, peneliti tertarik untuk melakukan penelitian kualitatif terkait perilaku penderita hipertensi. Penelitian ini bertujuan untuk memahami perilaku penderita hipertensi di Rumah Sakit X.

\section{METODE PENELITIAN}

Penelitian ini merupakan penelitian kualitatif berparadigma interpretif dengan metode fenomenologi untuk mengetahui secara mendalam terkait perilaku pasien hipertensi di Rumah Sakit X. Penelitian dilaksanakan sejak 25 November hingga 5 Januari 2021 yang melibatkan sejumlah enam informan sebagai pasien hipertensi di ruang rawat inap. Data diperoleh dari proses wawancara terhadap informan, 
observasi dan analisis dokumen. Analisis data perilaku terbagi dalam tiga tahap menurut Miles dan Huberman dalam Gora (2019) yaitu reduksi, penyajian data dan penarikan kesimpulan. Pengecekan keabsahan temuan menggunakan teknik triangulasi.

\section{HASIL}

\section{Penerapan diet rendah garam}

Perilaku diet rendah garam bagi penderita hipertensi telah diterapkan dalam kehidupan sehari-hari dan disampaikan oleh informan saat wawancara sebagai berikut:

"Diet garam yang saya ketahui yaitu garam menyebabkan tensi semakin tinggi atau naik, sehingga bagi yang menderita bipertensi, itu harus diet garam, kurangi mengkonsumsi garam maksudnya." (Informan Bapak IMS).

Informan memberikan pernyataan terkait siapa saja yang membantu penerapan diet, sebagai berikut :

"Istri saya sendiri yang sangat membantu saya dengan selalu mengingatkan untuk mengkonsumsi garam dalam jumlah yang memang sudah diatur satu sendok kurang lebih. Satu sendok teh."(Informan Bapak IWA).

\section{Penghentian konsumsi rokok dan alkohol}

Informan Ibu TKA menyatakan pemahamannya terkait dampak perilaku merokok dan konsumsi alkohol bagi penderita hipertensi.

"Kalau itu saya juga tabu bahwa dapat memicu tekanan darah tinggi, juga penyakit jantung jikea merokok. Saya tidak merokok juga tidak minum alkohol."

\section{Peningkatan aktivitas fisik dan olahraga}

Pernyataan disampaikan oleh Informan Ibu PD yang telah menerapkan aktivitas fisik rutin dan merasakan manfaatnya.

"Setiap hari, sejak mulai tahu tensi saya cukup tinggi, secara rutin setiap bangun tidur saya melakukan olabraga ringan jalan kaki 45 menit. Saya merasakan sangat ada perbedaannya sebelum dan sesudab saya berolahraga. Sebelum saya olabraga setiap hari, tensi saya sering tinggi. Setelah saya berolahraga, selama beberapa bulan ini, tensi saya cukup stabil."

Pengaturan kebutuhan tidur dan istirahat

Alasan mengapa tidur dan istirahat dianggap penting bagi penderita hipertensi seperti yang diungkapkan oleh Informan Ibu L.

"Karena dengan cukup istirahat biasanya membantu untuk tekanan darab kita lebih stabil, itu yang saya rasakan. Terus, imun kita juga lebih ini, jadinya lebih bagus."

\section{Penerapan metode kontrol stres}

Penyebab kemunculan stres dan cara yang biasa diterapkan informan dalam menangani stres salah satunya diungkapkan oleh Informan Bapak S. 
Nursing News: Jurnal Ilmiah Keperawatan, Vol 5, No 2 Tahun 2021 ,hal 45-55

Beliau juga menyampaikan bahwa bantuan pasangan sangat penting.

"Kemungkinan stresor dari sendiri termasuk. keluarga, dan pekerjaan, seperti itu yang saya rasakan sendiri sebagai pasien. Kemudian, cara mengatasiny a yaitu jalan-jalan, ke tempat yang sejuk, duduk, santai, tentunya dibantu istri."

\section{Pengobatan dan perawatan hipertensi}

Pengalaman dalam mengikuti pengobatan dan yang mendukung usaha pengobatan diungkapkan oleh informan Bapak S.

"Kalau obat hipertensi, selama saya konsumsi, pasti tensi saya menjadi stabil. Artinya, faktor risiko kita jadi berkurang untuk terkena penyakit yang lain. Terkait kesulitan, sementara sekarang ini kalau saya lihat, tidak ada kesulitan, di rumah yang paling berperan yaitu istri."

Namun, ada juga informan menyatakan hal yang berbeda seperti yang diungkapkan Bapak IMS.

"Saya jarang kontrol ke dokter. Tapi saya punya tensimeter. Di rumah saya cek, kalau memang tensi saya sampai 150 saya lebih lagi diet, diet garamnya dan saya beraktivitas semakin sering dan berusaba untuk tidak stres."

\section{PEMBAHASAN}

\section{Penerapan diet rendah garam}

Pernyataan yang disampaikan oleh informan terkait perilaku diet rendah garam menunjukkan bahwa informan telah memahami tentang diet rendah garam bagi penderita hipertensi. Kesadaran penderita hipertensi dalam menerapkan perilaku ini dilakukan atas dasar manfaat yang dirasakan antara lain tekanan darah lebih stabil serta terhindar dari berbagai keluhan kesehatan yang mengganggu.

Penerapan konsumsi diet garam oleh informan dalam penelitian ini telah sesuai dengan rekomendasi diet bagi pasien hipertensi. Prinsip dari penerapan diet rendah garam didasari atas rekomendasi Dietary Approaches to Stop Hypertension (DASH) dengan tidak mengkonsumsi garam lebih dari 5 gram/hari atau setara dengan satu sendok teh (Seangpraw et al., 2019). Ketika penderita mampu mengkonsumsi kurang dari 5 gram per hari akan bermanfaat untuk menurunkan tekanan darah, risiko penyakit kardiovaskular, stroke dan serangan jantung koroner (World Health Organization, 2020).

Penelitian oleh Huang et al., (2018) menemukan bahwa aplikasi restriksi garam bagi penderita hipertensi di rumah menunjukkan perkembangan kontrol tekanan darah yang lebih baik terutama sistolik. Pan et al., (2019) menemukan bahwa upaya pencegahan yang dapat 
terukur seperti pembatasan konsumsi garam didasari atas kesadaran pasien dalam memahami kondisi penyakitnya.

\section{Penghentian konsumsi rokok dan alkohol}

Hasil wawancara menunjukkan bahwa informan telah mengetahui dampak konsumsi rokok dan alkohol terhadap tekanan darah sehingga tidak melakukannya. Penerapan menghentikan konsumsi rokok dan alkohol bagi informan dalam penelitian ini telah sesuai untuk penderita hipertensi. Konsumsi alkohol sangat berpengaruh terhadap peningkatan signifikan risiko stroke pada konsumsi sebesar 80 gram/hari atau setara dengan 4 gelas bir. Konsumsi rokok juga sangat tidak disarankan pada penderita kondisi kronis sebab dapat meningkatkan eksaserbasi penyakit dan komplikasi yang lebih serius (Beevers et al., 2015).

Mekanisme yang terjadi akibat induksi alkohol termasuk pada ketidakseimbangan sistem saraf, stimulasi endotel untuk melepaskan endothelin, penghambatan dari produksi nitrit oksida endotelium serta stimulasi sistem renin angiotensin aldosteron atau kortisol, penipisan kalsium atau magnesium dan peningkatan kalsium intraseluler atau elektrolit pada pembuluh darah, ditengarai dimediasi oleh perubahan pada membran transportasi elektrolit (Kazim et al., 2016). Sedangkan pada rokok, penelitian oleh Saladini et al., (2016) membuktikan efek merugikan konsumsi rokok terhadap tekanan darah terutama bagi penderita hipertensi. Konsumsi rokok mempercepat proses kekakuan dinding arteri seiring pertambahan usia. Secara khusus pada efek rokok terhadap pembuluh darah, ditemukan efek vasokonstriksi yang kuat dan penghambatan pelepasan nitrit oksida yang disebabkan oleh kerusakan vasodilatasi endotel. Selain itu, ditemukan akumulasi oksigen aktif dan radikal bebas selama merokok, berdampak pada stres oksidatif sehingga terjadi disfungsi endotel, vasokontriksi dan inflamasi vaskular.

\section{Peningkatan aktivitas fisik dan olahraga}

Berdasarkan keterangan informan terkait berbagai aktivitas fisik dan olahraga yang dilakukan menunjukkan bahwa mereka telah memahami berolahraga dapat membantu melancarkan peredaran darah sehingga kontrol tekanan darah dapat menjadi lebih mudah. Aktivitas fisik umumnya dilakukan dengan durasi 30 menit setiap harinya dengan waktu antara pagi atau sore hari. Peningkatan aktivitas fisik dan olahraga oleh informan dalam 
penelitian ini telah mendekati kesesuaian kebutuhan akan aktif secara fisik bagi penderita hipertensi. Aktif secara fisik tidak hanya bermanfaat bagi penderita hipertensi untuk mengontrol tekanan darah, namun juga ditujukan untuk mengontrol berat badan, menguatkan jantung serta menurunkan tingkat stres. Aktivitas fisik dan olahraga yang disarankan setidaknya selama 150 menit dalam seminggu yang dibagi ke dalam 30 menit aktivitas sebanyak lima kali dalam satu minggu seperti jalan cepat yang diikuti dengan latihan fleksibilitas dan peregangan serta penguatan otot (American Heart Association, 2016).

Taft et al., (2018) menyatakan dalam penelitiannya bahwa aktivitas fisik dapat berkaitan dengan kondisi tekanan darah khususnya sistolik. Pernyataan ini didukung oleh penelitian Hegde \& Solomon, (2015) yang menyebutkan bahwa penurunan tekanan darah pada aktivitas fisik rutin berkaitan dengan pelemahan resistensi vaskular perifer oleh karena reaksi neurohormonal dan penurunan aktivitas saraf simpatis serta peningkatan diameter lumen arteri.

\section{Pengaturan kebutuhan tidur dan istirahat}

Berdasarkan keterangan dari informan, dapat diketahui bahwa malam hari merupakan waktu yang paling tepat untuk beristirahat. Kurang tidur memiliki dampak terhadap munculnya keluhan kesehatan akibat kenaikan tekanan darah, begitupun sebaliknya ketika tekanan darah meningkat maka akan mengganggu pola tidur penderitanya. Keluhan yang sering ditimbulkan antara lain sakit kepala, pusing disertai tegang pada tengkuk.

Aplikasi pengaturan kebutuhan tidur bagi informan dalam penelitian ini telah menyesuaikan dengan pentingnya pemenuhan kebutuhan istirahat bagi penderita hipertensi. Peningkatan tekanan darah hanya salah satu dari banyak risiko kesehatan yang dapat ditimbulkan karena kurang tidur, kesulitan untuk memulai tidur atau mempertahankan tidur. Meskipun insomnia sering dikaitkan dengan kesulitan tidur di malam hari, namun seseorang dengan insomnia kronis juga data mengalami kesulitan untuk tidur siang hari yang akan semakin meningkatkan risiko tekanan darah tinggi (Harvard Health, 2015).

Pada studi yang dilakukan oleh Aggarwal et al., (2018), menemukan bahwa pola tidur merupakan faktor prediksi yang signifikan 
untuk tekanan darah sistolik dan diastolik. Kualitas tidur yang buruk berdampak pada tekanan darah sistolik yang lebih tinggi. Penelitian oleh Hwang et al., (2015) mendukung studi tersebut dengan menemukan dalam penelitiannya terkait durasi tidur dengan hipertensi. Seseorang yang memiliki kualitas tidur rendah yaitu kurang dari lima jam dalam sehari memiliki tekanan darah yang lebih tinggi dan frekuensi rekomendasi obat yang lebih banyak jika dibandingkan dengan durasi tujuh jam tidur per hari. Studinya menemukan durasi waktu terbaik untuk tidur bagi penderita hipertensi adalah sekitar tujuh jam. Aktivasi sistem saraf simpatis menjelaskan hubungannya dengan durasi tidur yang pendek terhadap prevalensi hipertensi. Ketika durasi tidur semakin singkat, kondisi sadar akan mempertahankan stimulasi sistem saraf simpatis, sehingga berdampak pada peningkatan tekanan darah dan akan semakin parah dengan konsumsi garam berlebih.

\section{Penerapan metode kontrol stres}

Seperti yang diungkapkan oleh para informan, bahwa stres yang dialami dapat berasal dari dalam maupun luar diri masing-masing informan. Stres karena beban pekerjaan paling sering menimbulkan gangguan yang dirasakan oleh informan. Cara yang biasa dilakukan untuk menurunkan stres antara lain dengan mencari lokasi yang tenang untuk relaksasi sejenak serta melibatkan orang terdekat dalam upaya tersebut.

Kemampuan informan mengenali stres dan menemukan upaya meredakan stres telah mendukung perilaku meningkatkan kesehatan. Stres ditemukan secara konsisten memiliki hubungan dengan kondisi tekanan darah sistolik dan diastolik yang dikenal sebagai faktor risiko yang penting pada gangguan dan serangan kasus kardiovaskular (Taft et al., 2018). Stres psikologis akan menimbulkan peningkatan denyut jantung dan tekanan darah (Carroll, 2019). Stres utamanya menyebabkan peningkatan pada tekanan darah diastolik seperti pada hasil penelitian oleh (Ringoir et al., 2014). Peningkatan tekanan darah diastolik setidaknya akan mencapai rata-rata sebesar $96 \mathrm{mmHg}$ sebagai akibat dari peningkatan resistensi total vaskular.

\section{Pengobatan dan perawatan hipertensi}

Secara umum, penderita hipertensi menjalani pengobatan dan kontrol rutin mengikuti anjuran dokter. Mereka menjalani kontrol rutin karena bertujuan 
untuk mengetahui perkembangan kondisi kesehatan yang dialami selama menjalani pengobatan, namun masih ada informan yang tidak rutin kontrol jika tekanan darahnya tidak mencapai $150 \mathrm{mmHg}$ dari hasil pengukuran mandiri.

Perilaku rutin kontrol kondisi kesehatan bagi informan dengan hipertensi telah mendukung pemeliharaan kesehatan, namun masih ditemukan informan yang belum melakukannya karena merasa kondisinya belum membutuhkan pengecekan kesehatan ke pelayanan kesehatan. Kepatuhan dalam pengobatan hipertensi membutuhkan motivasi yang kuat dari individu untuk mengikuti anjuran pengobatan yang telah ditetapkan (Steele \& Robinson, 2018). Kepatuhan dalam pengobatan akan memberikan dampak optimal pada kasus hipertensi apabila disertai dengan pembatasan alkohol dan rokok, restriksi garam, kontrol berat badan, aktivitas fisik dan manajemen stres (Park \& Kim, 2016). Dalam penelitiannya, Cano-Gutierrez et al., (2015) menemukan bahwa salah satu penyebab ketidakpatuhan seseorang terhadap pengobatan hipertensi yaitu rendahnya perhatian terhadap kondisi kesehatan, sedangkan intervensi pada hipertensi tidak hanya mencakup pengobatan namun juga pencegahan komplikasi.

\section{KESIMPULAN}

Tenaga kesehatan yang merawat pasien hipertensi sebaiknya meningkatkan edukasi pada pasien dan keluarga tentang pentingnya penerapan pola hidup sehat secara mandiri, mengenali keluhankeluhan yang membahayakan, serta kontrol rutin ke pelayanan kesehatan. Tenaga kesehatan yang merawat pasien hipertensi sebaiknya meningkatkan edukasi pada pasien dan keluarga tentang pentingnya penerapan pola hidup sehat secara mandiri, mengenali keluhankeluhan yang membahayakan, serta kontrol rutin ke pelayanan kesehatan.

\section{REFERENSI}

Aggarwal, B., Makarem, N., Shah, R., Emin, M., Wei, Y., St-Onge, M., \& Jelic, S. (2018). Effects of Inadequate Sleep on Blood Pressure and Endothelial Inflammation in Women: Findings From the American Heart Association Go Red for Women Strategically Focused Research Network. Journal of the American Heart Association, $7(12)$. https://doi.org/10.1161/JAHA.118. 008590

American Heart Association. (2016). Getting Active to Control High Blood Pressure. High Blood Pressure. https://www.heart.org/en/healthtopics/high-bloodpressure/changes-you-can-make-to- 
manage-high-blood-

pressure/getting-active-to-controlhigh-blood-pressure

Beevers, D. G. (D. G., Lip, G. Y. H., \& O'Brien, E. (2015). ABC of bypertension. BMJ Books/Blackwell.

Bell, K., Candidate, P., \& Olin, B. R. (2015). Hypertension: The Silent Killer: Updated JNC-8 Guideline Recommendations.

Cano-Gutierrez, C., Reyes-Ortiz, C. A., Samper-Ternent, R., Gélvez-Rueda, J. S., \& Borda, M. G. (2015). Prevalence and Factors Associated to Hypertension among Older Adults in Bogotá, Colombia. Journal of Aging and Health, 27(6), 1046-1065. https://doi.org/10.1177/089826431 5573518

Carroll, D. (2019). Health Psychology: Stress, Behaviour And Disease. Routledge.

Cherfan, M., Vallée, A., Kab, S., Salameh, P., Goldberg, M., Zins, M., \& Blacher, J. (2020). Unhealthy behaviors and risk of uncontrolled hypertension among treated individuals-the conStAnceS population-based study. Scientific Reports Nature Research. https://doi.org/10.1038/s41598020-58685-1

Dinas Kesehatan Kota Denpasar. (2018). Profil Dinas Kesehatan Kota Denpasar.

Gebremichael, G. B., Berhe, K. K., \& Zemichael, T. M. (2019). Uncontrolled hypertension and associated factors among adult hypertensive patients in Ayder comprehensive specialized hospital, Tigray, Ethiopia, 2018. BMC Cardiovascular Disorders, 19(121). https://doi.org/10.1186/s12872019-1091-6

Gora, R. (2019). Riset kualitatif public relations. Jakad Publishing.

Harvard Health. (2015). Trouble falling asleep linked to high blood pressure. Harvard Health

Letter. https://www.health.harvard.edu/dis eases-and-conditions/trouble-fallingasleep-linked-to-high-blood-pressure Hegde, S. M., \& Solomon, S. D. (2015). Influence of Physical Activity on Hypertension and Cardiac Structure and Function. Current Hypertension Reports, 17(10), 77. https://doi.org/10.1007/s11906015-0588-3

Huang, B., Li, Z., Wang, Y., Xia, J., Shi, T., Jiang, J., Nolan, M. T., Li, X., Nigwekar, S. U., \& Chen, L. (2018). Effectiveness of self-management support in maintenance haemodialysis patients with hypertension: A pilot cluster randomized controlled trial. Nephrology, 23(8), 755-763. https://doi.org/10.1111/nep.13098

Hwang, H.-R., Lee, J.-G., Lee, S., Cha, K. S., Choi, J. H., Jeong, D.-W., Yi, Y.H., Cho, Y.-H., Tak, Y.-J., \& Kim, Y.J. (2015). The relationship between hypertension and sleep duration: an analysis of the fifth Korea National Health and Nutrition Examination Survey (KNHANES V-3). Clinical Hypertension, 21(1), 1-7. https://doi.org/10.1186/s40885015-0020-y

Kario, K., Chen, C.-H., Park, S., Park, C.G., Hoshide, S., Cheng, H.-M., Huang, Q.-F., \& Wang, J.-G. (2018). Consensus Document on Improving Hypertension Management in Asian Patients, Taking Into Account Asian Characteristics. Hypertension, 71(3), 375-382.

https://doi.org/10.1161/HYPERT

ENSIONAHA.117.10238

Kazim, S., Ansar, R. A., \& Husain, K. (2016). Alcoholic Beverages-Induced Hypertension And Its Management. Journal of Pharmacentical and Life Sciences WJPLS, 2(5), 311-338.

Kemenkes RI. (2018). Hasil Utama Riskesdas 2018. 
Pan, J., Wu, L., Wang, H., Lei, T., Hu, B., Xue, X., \& Li, Q. (2019). Determinants of hypertension treatment adherence among a Chinese population using the therapentic adherence scale for bypertensive patients. https://doi.org/10.1097/MD.00000 00000016116

Park, E., \& Kim, J. (2016). The Impact of a Nurse-Led Home Visitation Program on Hypertension SelfManagement among Older Community-Dwelling Koreans. Public Health Nursing, 33(1), 42-52. https://doi.org/10.1111/phn.12220

Pu, J., Chewning, B. A., Johnson, H. M., Vanness, D. J., Young, H. N., \& Kreling, D. H. (2015). Health behavior change after blood pressure feedback. PLOS ONE, 10(10), 1-12. https://doi.org/10.1371/journal.pon e.0141217

Rahmawati, R., \& Bajorek, B. (2018). Understanding untreated hypertension from patients' point of view: A qualitative study in rural Yogyakarta province, Indonesia. Chronic Illness, 14(3), 228-240. https://doi.org/10.1177/174239531 7718034

Ringoir, L., Pedersen, S. S., Widdershoven, J. W. M. G., \& Pop, V. J. M. (2014). Prevalence of psychological distress in elderly hypertension patients in primary care. Neth Heart J. https://doi.org/10.1007/s12471013-0502-z

Saladini, F., Benetti, E., Fania, C., Mos, L., Casiglia, E., \& Palatini, P. (2016). Effects of smoking on central blood pressure and pressure amplification in hypertension of the young. Vascular Medicine (United Kingdom), 21(5), 422428.

https://doi.org/10.1177/1358863X1 6647509

Seangpraw, K., Auttama, N., Tonchoy, P., \& Panta, P. (2019). The effect of the behavior modification program Dietary Approaches to Stop Hypertension (DASH) on reducing the risk of hypertension among elderly patients in the rural community of Phayao, Thailand. Journal of Multidisciplinary Healthcare, 12 , 109-118. https://doi.org/10.2147/JMDH.S18 5569

Soenarta, A. A., Buranakitjaroen, P., Chia, Y., Chen, C., Nailes, J., Hoshide, S., Minh, H. Van, Park, S., Shin, J., Siddique, S., Sison, J., Sogunuru, G. P., Sukonthasarn, A., Tay, J. C., Teo, B. W., Turana, Y., Verma, N., Wang, T., Zhang, Y., ... Kario, K. (2020). An overview of hypertension and cardiac involvement in Asia: Focus on heart failure. The Journal of Clinical Hypertension, 22(3), 423-430. https://doi.org/10.1111/jch.13753

Steele, R., \& Robinson, M. (2018). Family Health Care Nursing: Theory, Practice, and Research - Joanna Rowe Kaakinen, Deborah Padgett Coeblo, Rose Steele, Melissa Robinson - F.A Davis Company Taft, C., Hallberg, I., Bengtsson, U., Manhem, K., \& Kjellgren, K. (2018). Links between blood pressure and medication intake, well-being, stress, physical activity and symptoms reported via a mobile phone-based self-management support system: a cohort study in primary care. $B M J$ Open, $\quad$ 8(8), e020849. https://doi.org/10.1136/bmjopen2017-020849

World Health Organization. (2019). World Hypertension Day 2019.

World Health Organization. (2020). Salt reduction. Salt Reduction. https://www.who.int/news$\mathrm{room} /$ fact-sheets/detail/saltreduction 